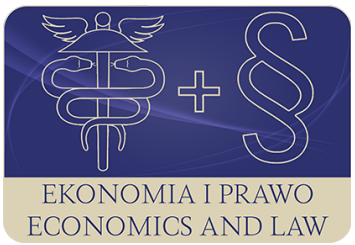

EKONOMIA I PRAWO. ECONOMICS AND LAW

Volume 18, Issue 2, June 2019

p-ISSN 1898-2255, e-ISSN 2392-1625

www.economicsandlaw.pl

EKONOMIA I PRAWO
ECONOMICS AND LAW

ORIGINAL ARTICLE

received 15.07.2018; revised 27.01.2019; accepted 30.06.2019

Citation: Legiędź, T. (2019). The economic consequences of the recent political changes in China: the new institutional economics perspective. Ekonomia i Prawo. Economics and Law, 18(2): 197-208.

doi:10.12775/EiP.2019.015.

\title{
The economic consequences of the recent political changes in China: the new institutional economics perspective
}

\author{
TOMASZ LEGIĘDŹ
}

University of Lodz, Faculty of Economics and Sociology, Department of Development Economics, ul. Rewolucji 1905 r., 41, 90-214 Łódź, Poland

๑legiedz@uni.lodz.pl

orcid.org/0000-0001-9396-0729

\begin{abstract}
Motivation: Over 30 years ago, Deng Xiaoping had the two-term limit on the presidency inscribed in the constitution of China. It was part of Deng's plan to institutionalize leadership changes in China, to avoid a return to one-man rule. This solution has ensured political stability which undoubtedly had a positive impact on economic growth in the following decades. However, in March 2018, the National People's Congress of China approved the removal of the two-term limit on the presidency. Moreover, president Xi Jinping consolidated his political power as the party voted to enshrine his name and political ideology in the party's constitution - elevating his status to the level of its founder, Chairman Mao.

Aim: The purpose of this article is to analyse the impact of recent changes in the political system of China on the Chinese economy as well as the chances for further development of this country. The paper applies the new institutional economics perspective, particularly, the limited and open access orders framework proposed by D.C. North, J.J Wallis, and B.R. Weingast.

Results: The article will present arguments proving that recent political changes in China will negatively affect growth and economic development. The concentration of power in the hands of one man could be a symptom of regression of the limited access order, which, according to North, Wallis, and Weingast affects not only the economy but also could increase the risk of violence.
\end{abstract}


Keywords: people's Republic of China; new institutional economics; economic development; social order

JEL: B52; O10; 053

\section{Introduction}

Since the beginning of market reforms in the late 70s of the twentieth century the pace of economic growth in China has been spectacular'. In terms of purchasing power parity, the economy of the People's Republic of China (PRC) is currently the largest in the world (World Bank, 2017). However, considering per capita production, China is still considerably poorer than the developed countries. In 2014 GDP per capita weighted by purchasing power parity amounted to less than $24 \%$ of the US production (Feenstra et al., 2015, pp. 3150-3182). A similar level of development was achieved by South Korea in the mid-1980s, when the process of political changes leading to the democratisation of the authoritarian regime accelerated ${ }^{2}$. Thus, the currently occurring changes in the political and economic system in the PRC are very interesting. Everything points to the fact that in the case of China there is no chance of widening the scope of political freedom in the near future. Recent events indicate that China's political system is becoming more repressive and centralised. In March 2018 the National People's Congress abolished presidential term limits, which will enable the current leader Xi Jinping to proceed with the consolidation of power. At the same time, political repression and censorship are becoming increasingly conspicuous.

The aim of the article is to analyse the impact of changes in the political system of China on the rate of economic growth and the chances for further development of this country. The analysis is conducted from the perspective of the new institutional economics, mainly the theoretical concept by D.C. North et al. (2007, 2009, 2013). The first section presents the above-mentioned theory, then the concept is employed to explain why the institutional order, which developed during the Deng Xiaoping reign, had a positive impact on the process of market reforms and the ongoing economic growth in China. In the further section of the article we demonstrate evidence whereby dismantling the institutional system, which already possessed a certain degree of openness, by President Xi Jinping may lead to a slowdown in China's economic growth. A literature review and case study have been carried out in this article.

${ }^{1}$ During the years 1978-2008, an average GDP growth rate was around 10\%, and during the last period it was still almost 7\% (World Bank, 2017).

2 In 1987, when the constitution was changed, and the democratic presidential elections were held, Korea's per capita GDP was around 26\% of the GDP per capita of the United States (Feenstra et al., 2015, pp. 3150-3182). 


\section{Growth and development in a limited access order: an outline of the theoretical concept of D.C. North, J.J. Wallis and B.R. Weingast}

The success of Chinese reforms and the continuing high rate of economic growth prompt some researchers to put forward a view that authoritarian Chinese governments have succeeded in creating a new model of economic development which may be a viable alternative to the Western development path (Halper, 2010; Ramo, 2004; Williamson, 2012, pp. 1-16). However, there is a widespread belief among researches that there are some conspicuous obstacles to sustainable growth and economic development within the autocratic system. First of all, it is pointed out that the vast majority of developed countries are democratic (Acemoglu et al., 2014; North et al., 2009; Rodrik, 1997) ${ }^{3}$ and therefore it appears that without significant changes in the political system it would be very difficult for any country to achieve the status of a developed state. Secondly, it is highlighted that the main impediment to the long-term economic growth in an autocratic system is the fact that ownership and contractual rights are never fully secured in such a system (Acemoglu \& Robinson, 2012; North et al., 2009; Olson, 1993, p. 574). Hence, in the case of China there emerge some doubts whether the state will be able to transform into a rich country without any significant enhancement of the scope of political freedom (Chen, 2013; Grinin et al., 2015, pp. 294-308; Herrington, 2011).

As it appears on the example of China, but also on the example of other countries, such as South Korea and Taiwan, a high rate of economic growth may persist even for several decades in spite of the existence of authoritarian rule. However, as it is claimed by North et al. (2009), as well as D. Acemoglu and J.A. Robinson (2012), it is impossible to maintain a sustained economic growth in countries where the access to political markets is limited. In order to account for the limits of growth and economic development within an autocratic system, one needs to first understand what makes growth in such conditions possible in the first place. In their concept, North et al. (2009) indicate that the condition which is necessary for initiating growth and development is violence reduction. According to them, there are two types of social order that currently predominate in the world - the limited access order (LAO) and the open access order (OAO). In a $\mathrm{LAO}$, violence is limited due to the emergence of a dominant coalition, which brings together individuals and organisations that can use violence. The dominating coalition restricts others' access to valuable resources and to activities that generate profits. The elites obtain economic rents, the source of which can be either extortion or corruption, as

3 The autocratic countries which can be included among developed countries are only Singapore and countries whose source of wealth are rich deposits of crude oil and natural gas: United Arab Emirates, Brunei, Saudi Arabia, Qatar and Kuwait. Due to the relatively low level of indicators determining the level of development beyond GDP per capita including Arab countries among the developed ones may be controversial. 
well as possession of land or licenses. Since an outbreak of violence could possibly lead to the reduction of these economic rents, the elites acknowledge that it is more profitable to cooperate than to fight. Thus, in a LAO, the political system is utilised by the authorities to regulate economic competition and obtain economic rents. In turn, economic rents are the main factor shaping social relations, controlling violence and establishing social cooperation (North et al., 2009, pp. 18-20). This type of order prevails in the societies of developing countries, and such order currently functions also in China.

North et al. (2007, p. 27) define development as a process of moving through consecutive forms of a LAO to an OAO. They emphasise that such a concept of development exposes the existence of two separate problems. The first problem is concerned with the way in which the development within a LAO is possible. It is crucial to seek an answer to the question of what conditions are conducive to reducing violence and subsequently driving the LAO development process. This process is essential for ensuring that an increasingly big part of society becomes involved in the processes of creative activity and therefore that the society is increasing its productivity. This problem mainly affects the poorest countries, where there is a great untapped potential of human work. To better explain the mechanism of triggering the creative forces of poor countries, North et al. (2009, p. 21) distinguish three basic evolution stages of a limited access order: fragile, basic, and mature. The maturation of a LAO means that increasingly organisations and individuals have access to political and economic markets. Hence competition increases, which positively affects economic growth. However, economic growth under a LAO is usually unstable. Giving development a permanent character is a second problem, whose solution requires overcoming an institutionally conditioned system based on violence and transitioning to an open access order. Many countries in the world have managed to create a relatively efficient economy and significantly raised the standard of living of many citizens. However, a large number of people still have a significantly impeded access to political and economic markets, and the differences between the rich and the poor are huge (this is currently the case in China). As a consequence, these countries fall into the violence trap, which has a strong institutional background (Cox et al., 2015). This stems from the paradox in the logic of the limited access system operation. On the one hand, thanks to the limitation of resource access, the elites ensure economic rents for themselves, thus limiting violence and creating conditions for economic growth. On the other hand, a lack of competition brings about inefficient allocation of resources, which in the long run leads to the limitation of the economic growth rate. A LAO is not static. In the case of a temporary escalation of violence, resulting from the competition for economic rents, it is strongly susceptible to crises. That is why states with such social order usually experience periods of relatively high economic growth, but also violent and long-lasting crises. Consequently, in the long-term there is usually no significant improvement in the quality of life of all the citizens (North et al., 2013). 


\section{Methods}

The analysis is conducted from the perspective of the new institutional economics, mainly the theoretical concept by North et al. (2007; 2009; 2013). The article uses the qualitative analysis method that includes literature review, descriptive analysis, and case study of the People's Republic of China. The applied method involves deductive analysis, as well as the analysis of cause-effect relationships concerning the impact of recent changes in the political system of China on further economic and political development of this country.

\section{Results}

\subsection{The limited access order in China: the collective leadership}

The problems in the functioning of a limited access order can be observed on the example of China during Mao Zedong's rule, when the country experienced frequent crises and even outbreaks of violence. During three decades, the communist authorities tried to create institutions of the centrally planned economy, which primarily meant Soviet-style industrialisation at the expense of the collectivised countryside (Naughton, 2007, p. 59). The authorities conducted this with the tools of political repression. These reforms resulted in overthrowing the traditional model of the Chinese economy, which almost always had a negative social and economic impact. What illustrates this is e.g. The Great Leap Forward, which was intended to lead to the immediate development of China and the achievement of the economic level of other socialist countries. Instead, the politics imposed by Mao Zedong caused the deaths of around 20-30 million Chinese people (Naughton, 2007, p. 72). As a result of such crises a political thaw took place, when solutions not always in line with socialist ideology, but effective in terms of improving the economic situation were applied. Local authorities often conducted this policy in spite of the central government $(\mathrm{Wu}$, 2005, pp. 110-111). However, when Mao Zedong recognised that such reforms could lead to the reduction of his power, he ordered another political campaign to be implemented, which aimed at removing political opponents. One of these campaigns was a cultural revolution that led to an outbreak of violence uncontrollable even by Mao (Naughton, 2007, pp. 74-75). Mao had a huge influence on politics, as, like the USSR before, China witnessed the emergence of the cult of the individual, which resulted from the political repression and the operation of the propaganda apparatus.

On the contrary, the heritage of Deng Xiaoping's government, another Chinese leader, was the collective leadership and division of power in the organisational structure of the party and the state (Hu, 2014, p. 5; Li, 2016; Naughton, 2018 , p. 32). It was the creation of a new, more stable dominating coalition, bringing together both party and military activists, that from the end of the 1970s 
allowed for the introduction of a series of economic reforms and, consequently, the entry onto the path of rapid economic growth and development. To reduce the risk of one-person rule, a new constitution was passed in 1982, which limited the office of the president and vice-president to a maximum of two terms. Although the position of the president of China is primarily representative, it has become customary that he also performs the role of the chairman of the Central Military Commission and the secretary general of the Chinese Communist Party (CCP), i.e. he exercises real power in China. Limiting the number of presidential terms meant that every decade the person leading the state and party authorities changed. This limited long-term concentration of power in the hands of one person, abuse by the governing class, and the risk of political crises similar to those which occurred during Mao's tenure.

Economic growth and political stability ${ }^{4}$ fostered the maturing of the limited access order in the following decades, although the Chinese political system itself did not change significantly. According to North et al. (2013), one-party political systems in the communist countries were an example of a basic LAO. However, at the same time they point out that the communist governments had a monopoly on the use of violence, which is usually difficult to achieve in a LAO and is a characteristic feature of an OAO. Unlike most of the modern examples of a LAO, the economies of the communist countries were under total control of the state and served the purposes of the Communist Party. Private organisations were of marginal importance, and all activities were controlled by the party (Connolly, 2013). A. Yakovlev (2012) even claims that many of the features of the communist system bore the hallmarks of the mature LAO. In the case of the hybrid system in China, there are even more characteristics of the more mature version of the LAO, as private enterprises play a significant role in the contemporary Chinese economy. However, it should be remembered that there is still a one-party system in China and the freedom of activity enjoyed by organisations, which are not directly controlled by the CCP, is very limited.

\subsection{Growth limits within the LAO in China}

According to North et al. (2009, p. 20) a condition for the stability of the socio-economic system is, on the one hand, the balance between the distribution and organisation of potential political violence and power and, on the other hand, the distribution and organisation of economic power. They call this double balance, because in order for society to remain stable, there must be not only balance within the benefits gained by the elites, but also political, economic, cultural, social and military systems must contain compatible systems regulating their activities. Therefore, fundamental transformation in the operation of the economy cannot take place without significant changes in the political

${ }^{4}$ Since the beginning of reforms in the late 1970s. In the 20th century, only one significant political crisis in China took place. It happened in 1989 during the students' protests on the Tiananmen Square. 
system. Similarly, the political system cannot evolve without changes in the economic sphere (North et al., 2009, p. 20).

There have been significant economic transformations over the last four decades in China, but when it comes to the political system, actually, the only significant change was the replacement of one-man power in the party by collective leadership. Although the scope of duties and responsibilities of local authorities has increased, these authorities are still strictly controlled by the Communist Party. The CCP still has a monopoly on power and the activity of political organisations against the will of the party is practically impossible. As a result, the institutional imbalance, resulting from the relatively large economic freedom enjoyed by the Chinese and from the lack of such freedom in political matters, is growing. On the one hand, the economic potential of the richest entrepreneurs' increases, and therefore the possibility of their impact on the political and economic system also increases. On the other hand, the increasingly affluent society, primarily the flourishing middle class, which thanks to the economic growth successfully satisfies its material needs, begins to demand increased political liberties and also draws more and more attention to the authorities' incompetence on issues such as ecology or still unresolved problem of widespread corruption.

Such course of events corresponds to the dynamics of social events taking place in the processes of economic growth under the LAO. According to the concept of North et al. (2009), in China, the order of limited access matures, but, at the same time, the imbalance between the openness of the political and economic system clearly increases. In this situation, two scenarios are possible. A widening of the dominating coalition by joining new members may occur, and, as a result, there is a chance that the rights possessed by the elites will gradually start to include the whole society or the authorities will decide to centralise the government by limiting economic and political freedoms. In order to make the transformation to an open access possible, three conditions must be met in accordance with the concept of North et al. (2009): (a) the rule of law for elites, (b) support for the perpetually lived organizations, both public and private, and (c) consolidated political control over organisations that can use violence (including army and police forces). In the case of modern China, still condition (c) is only met.

In the case of China, it was also possible to observe symptoms of upcoming political changes. As E.C. Economy (2014, p. 80) writes: 'he Chinese Communist Party, plagued by corruption and lacking a compelling ideology had lost credibility among the public, and social unrest was on the rise'. However, the growing imbalance between the openness of the economic and political system does not necessarily lead to liberalisation of the institutional system. Since the number of countries with open access is relatively small, one may risk a statement that in the situation of imbalance there is a much greater probability of limiting economic and political freedoms than of their increase. In the case of China under President Xi Jinping's reign, one can observe such a process, with its main symptom being the concentration of power in the hands of a single 
man (Fu \& Distelhorst, 2018, p. 100; Naughton, 2018, p. 32). The new President not only took over, as his predecessors, the three most important positions in the country, but, moreover, headed many other, also newly created groups of economic, military and political character. In this way, he questioned the current principles of collective leadership, becoming not only the 'first among equals', but simply the first one in the country (Economy, 2014, p. 82).

The current authorities of China declare introducing economic reforms assuming that the market forces will determine the allocation of resources. These reforms mainly refer to further restructuring of state-owned enterprises, which are still a significant part of the Chinese economy. At the same time, the government wants to control private enterprises to a greater extent. An example of this would be actions of the authorities towards the largest Chinese corporations of the new technology sector, such as Baidu, Tencent, and Alibaba. In order to control their activities more effectively, the government wants to take over part of the stock of these corporations, which should allow for more effective implementation of the country's economic policy and for the usage of technology to more effectively control citizens (Creemers, 2018). Private enterprises are also supposed to invest in state-owned enterprises, which means to help in their restructurisation. All these activities show that there is no chance to widen the dominant coalition in the nearest future. Research shows that $85 \%$ of Chinese people who have accumulated wealth of value exceeding one million US Dollars, plan to educate their children abroad, and $65 \%$ of those who have gathered at least 1.6 million US Dollars - leave China or plan to do so in the nearest future (Economy, 2014, p. 84).

The limitation of political freedoms is even more visible. Although during the Communist Party's rule civil liberties have always been limited, recently it can be observed that the censorship of both, traditional media and the Internet, has become much more stringent. When Xi took over power, repressions related to any symptoms of the formation of civil society in China became the main focus of a political campaign aimed at consolidating power. Such a policy is motivated by desire to ensure social stability (Fu \& Distelhorst, 2018, pp. 100-122). China government has banned academic research and teaching on seven topics: universal values, civil society, civil rights, freedom of the press, the historical errors of the Chinese Communist Party, crony capitalism, and the independence of the judiciary (Economy, 2014, p. 83). The legal system is also being reformed and its aim is to create a 'socialist rule of law with the Chinese characteristics' (Peerenboom, 2015, pp. 49-74; Zhang, 2017, pp. 373-400). Changes are to guarantee a monopoly on power for the party and to limit the influence of local authorities on the judicial system. The legal system is also to be based more on the constitution - the interpretation of which would be a prerogative of the Standing Committee of the National People's Congress. One of the paramount declared objectives of Xi's administration is the fight against corruption. The anti-corruption policy endorsed by the current president is also one of the main sources of his increasing support among Chinese people. Potentially, 
curbing corruption could lead to an increase in the openness of the economic system, but it is still difficult to say to what extent the current anti-corruption policy really cracks down on this negative phenomenon, and how much it is only a tool to fight the internal opposition. The concentration of power in the hands of President Xi was aimed to help him carry out the necessary economic reforms in order to keep China on the path of rapid economic growth. Although the growth rate has been still high, the first economic reforms announced for the beginning of Xi's tenure did not bring expected results (Naughton, 2018, p. 34$)^{5}$.

It should also be noted that, when it comes to South Korea and Taiwan, which developed rapidly under the autocratic system, and then evolved into liberal democracies, an important factor that forced the elites to open the political system was pressure from the Western allies (Legidź, 2018; Mo \& Weingast, 2013; You 2013). When it comes to China, which is of far greater international importance and is a superpower, such pressure is largely irrelevant, and thus potential democratisation is less likely.

\section{Conclusion}

The ongoing state economic policy indicates that the Chinese government is aware of the limitations of the current economic model, which is primarily based on cheap labour. However, if economists' convictions about the importance of economic and political freedom for the process of generating and consolidating economic growth are right, the currently adopted direction of political change in China will contribute to weakening the country's growth and development. In the light of the experiences of countries, which have achieved a high level of welfare and from the perspective of the dominating in economics conviction about the importance of liberal democracy for economic growth and development, it seems unlikely that the Chinese government will succeed in creating an institutional system that would ensure a monopoly of power for the CCP and will meet the conditions necessary for the functioning of a developed economy. However, it should be remembered that this concept is based mainly on the analysis of experience from the West, and thus from a different culture. As some researchers point out, the example of Singapore proves that a highly developed society can be created under a non-democratic system (Bell, 2015). It is also difficult to predict the effects of using new technologies that enable unprecedented surveillance and control of the society. Nevertheless, it seems that in the nearest future a significant slowdown in economic growth should be expected, since abolishing the system of power shaped during Deng Xiaoping's reign significantly increases the risk of conflict among the elites.

5 Third plenum of the Central Committee of the CCP announced in 2013 that it would carry out significant economic reforms, which were primarily intended to solve the problem of the restructurisation of debts of local governments and state-owned enterprises as well as to lead to greater openness of the stock exchange (Naughton, 2018, p. 34). 


\section{References}

Acemoglu, D., \& Robinson, J.A. (2012). Why nations fail: the origins of power, prosperity, and poverty. New York: Crown Publishers.

Acemoglu, D., Naidu, S., Restrepo, P., \& Robinson, J.A. (2014). Democracy does cause growth. NBER Working Paper Series, 20004. doi:10.3386/ w20004.

Bell, D.A. (2015). The China model: political meritocracy and the limits of democracy. Princeton: Princeton University Press.

Chen, J. (2013). A middle class without democracy: economic growth and the prospects for democratization in China. New York: Oxford University Press. doi:10.1093/ acprof:oso/9780199841639.001.0001.

Connolly, R. (2013). The economic sources of social order development in Post-Socialist Eastern Europe. London-New York: Routledge doi:10.4324/9780203095355.

Cox, G.W., North, D.C., \& Weingast, B.R. (2015). The violence trap: a political-economic approach to the problems of development. SSRN Electronic Journal. doi:10.2139/ssrn.2370622.

Creemers, R. (2018). Disrupting the Chinese state: new actors and new factors. Asiascape: Digital Asia, 5(3). doi:10.1163/22142312-12340094.

Economy, E.C. (2014). China's imperial president Xi Jinping tightens his grip. Foreign Affairs, 93(6).

Feenstra, R.C., Inklaar, R., \& Timmer, M.P. (2015). The next generation of the Penn World Table. American Economic Review, 105(10). doi:10.1257/ aer.20130954.

Fu, D., \& Distelhorst, G. (2018). Grassroots participation and repression under $\mathrm{Hu}$ Jintao and Xi Jinping. The China Journal, 79. doi:10.1086/694299.

Grinin, L., Tsirel, S., \& Korotayev, A. (2015). Will the explosive growth of China continue? Technological Forecasting and Social Change, 95. doi:10.1016/j. techfore.2014.06.023.

Halper, S. (2010). The Beijing consensus: how China's authoritarian model will dominate the twenty-first century. New York: Basic Books.

Herrington, L.M. (2011). Why the rise of China will not lead to global hegemony. Retrieved 27.01.2019 from http://www.e-ir.info.

$\mathrm{Hu}$, A. (2014). China's collective presidency. Heidelberg: Springer. doi:10.1007/978-3-642-55279-3.

Legiedź, T. (2018). From limited access to open access order in Taiwan. Journal of the Asia Pacific Economy. doi:10.1080/13547860.2018.1503767.

Li, C. (2016). Chinese politics in the Xi Jinping era: reassessing collective leadership. Washington: Brookings Institution Press.

Mo, J., \& Weingast, B.R. (2013). Korean political and economic development. Cambridge: Harvard University Asia Center. doi:10.2307/j.cttlx07wgf.

Naughton, B. (2007). The Chinese economy: transitions and growth. Cambridge: MIT Press. 
Naughton, B. (2018). Is there a Xi Jinping model of economic reform? In H. Zhou, \& W.C. Huang (Eds.), The impacts of China's rise on the pacific and the world. Kalamazoo: W.E. Upjohn Institute for Employment Research. doi:10.17848/9780880996358.ch3.

North, D.C., Wallis, J.J., \& Weingast, B.R. (2009). Violence and social orders: a conceptual framework for interpreting recorded human history. Cambridge: Cambridge University Press. doi:10.1017/CBO9780511575839.

North, D.C., Wallis, J.J., Webb, S.B., \& Weingast, B.R. (2007). Limited access orders in the developing world: a new approach to the problems of development. The World Bank Policy Research Working Papers. doi:10.1596/1813-9450-4359.

North, D.C., Wallis, J.J., Webb, S.B., \& Weingast, B.R. (2013). Limited access orders: an introduction to the conceptual framework. In D.C. North, J.J. Wallis, S.B. Webb, \& B.R. Weingast (Eds.), In the shadow of violence: politics, economics, and the problems of development. New York: Cambridge University Press. doi:10.1017/CBO9781139013611.001.

Olson, M. (1993). Dictatorship, democracy, and development. American Political Science Review, 87(3). doi:10.2307/2938736.

Peerenboom, R. (2015). Fly high the banner of socialist rule of law with Chinese characteristics! Hague Journal on the Rule of Law, 7(1). doi:10.1007/ s40803-015-0003-9.

Ramo, J.C. (2004). The Beijing consensus. London: Foreign Policy Centre.

Rodrik, D. (1997). Democracy and economic performance. Retrieved 27.01.2019 from https://drodrik.scholar.harvard.edu.

Williamson, J. (2012). Is the 'Beijing consensus' now dominant? Asia Policy, 13(1). doi:10.1353/asp.2012.0012.

World Bank. (2017). World development indicators. Retrieved 27.02.2019 from https://datacatalog. worldbank.org.

$\mathrm{Wu}, \mathrm{J}$. (2005). Understanding and interpreting Chinese economic reform. Mason: Thomson/South-Western.

Yakovlev, A. (2012). Communist creed and its impact on the development of the economy and society: application of new approach of Douglass North to the analysis of the USSR historical experience. Mir Rossii, 21(4).

You, J.S. (2013). Transition from a limited access order to an open access order: the case of South Korea. In D.C. North, J.J. Wallis, S.B. Webb, \& B.R. Weingast (Eds.), In the shadow of violence: politics, economics, and the problems of development. New York: Cambridge University Press. doi:10.1017/ CBO9781139013611.001.

Zhang, X. (2017). Rule of law within the Chinese party-state and its recent tendencies. Hague Journal on the Rule of Law, 9(2). doi:10.1007/s40803-017-0052-3. 


\section{Acknowledgements}

Author contributions: author has given an approval to the final version of the article.

Funding: this research was funded by the University of Lodz, Faculty of Economics and Sociology, Department of Development Economics statutory sources.

Note: the results of this study were presented at Second Scientific Conference Institutions: theory and practice (June, 19-20 2018, Torun, Poland). 